\title{
Flaxseed supplementation improves fatty acid profile of cow milk
}

\author{
M. Caroprese, ${ }^{*} \dagger^{1}$ A. Marzano, ${ }^{*}$ R. Marino, ${ }^{*}$ G. Gliatta, ${ }^{*}$ A. Muscio, ${ }^{*}$ and A. Sevi ${ }^{*} \dagger$ \\ ${ }^{*}$ Dipartimento PRIME, and \\ †Istituto per la Ricerca e le Applicazioni Biotecnologiche per la Sicurezza e la Valorizzazione dei Prodotti Tipici e di Qualità (BIOAGROMED), \\ Università di Foggia, Via Napoli 25, 71100 Foggia, Italy
}

\begin{abstract}
The objective of the study was to determine the effects of adding flaxseed or fish oil to the diet on the milk fatty acid profile of cows. The experiment was conducted in the summer of 2006 and involved 24 Friesian cows that were divided into 3 groups of 8 animals according to different type of fat supplementation: a traditional diet with no fat supplementation, a diet supplemented with whole flaxseed, and a diet supplemented with fish oil. Results suggested that whole flaxseed supplementation positively affects the milk fatty acid profile during summer. In particular, milk from cows receiving flaxseed supplementation showed a decrease in saturated fatty acid, an increase in monounsaturated fatty acid, and, together with the milk from fish oil-supplemented cows, an increase in polyunsaturated fatty acid content compared with milk from control cows. As expected, both fish oil and flaxseed supplementation increased the content of n-3 polyunsaturated fatty acids in milk fat. The increased dietary intake of C18:3 in flaxseedsupplemented cows resulted in increased levels of milk C18:1 trans-11 and increased conjugated linoleic acid C18:2 cis-9,trans-11 by $\Delta^{9}$-desaturase activity. Milk from flaxseed-supplemented cows together with the high conjugated linoleic acid content was characterized by low atherogenic and thrombogenic indices, suggesting that its use has less detrimental effects concerning the atherosclerosis and coronary thrombosis risk associated with the consumption of milk and dairy products. In conclusion, flaxseed supplementation improves composition and nutritional properties of milk from cows milked during times of high ambient temperature.
\end{abstract}

Key words: flaxseed, fish oil, dairy cow, fatty acid

\section{INTRODUCTION}

Southern Italy is characterized by a typical Mediterranean climate that undergoes extended periods of high environmental temperatures, relative humidity, and solar radiation during summer. Cows show as much

Received December 29, 2008.

Accepted February 26, 2010.

${ }^{1}$ Corresponding author: m.caroprese@unifg.it as a $40 \%$ decrease in feed intake at $40^{\circ} \mathrm{C}$, combined with reduced milk production and a change in milk composition during summer (Kadzere et al., 2002). In addition, high ambient temperature has a direct effect on reducing the secretory ability of udder cells (Silanikove, 1992). In the past, the maintenance of milk production has been obtained by reducing the fiber and increasing the concentrate in the diet, improving the efficiency of metabolized energy utilization of cows (West et al., 1999). Recently, supplemental rumen-protected fats of different sources had been administrated to heat-stressed dairy cows to improve their physiological responses and production (Chan et al., 1997; Moore et al., 2005; Liu et al., 2008).

Oilseeds are rich in polyunsaturated fatty acids (PUFA), which can be fed to dairy animals to modify the milk fatty acid (FA) profile and produce a more nutritionally beneficial milk for human consumption (Kennelly, 1996). Feeding flaxseed to dairy cows decreases the concentrations of short- and medium-chain FA and increases the long-chain FA content in milk fat (Mustafa et al., 2003; Petit, 2003). On the other hand, fish oil addition to dairy cows diet has been suggested to specifically increase the long-chain n-3 FA and C20:5 eicosapentaenoic acid (EPA) and C22:6 docosahexaenoic acid (DHA) contents in milk (Chilliard et al., 2001).

Conjugated linoleic acid (CLA) isomers are a group of linoleic acid isomers, mainly contained in dairy products, that are considered to have anticarcinogenic, antiatherogenic, and antiobesity effects and immunomodulatory properties (McGuire and McGuire, 2000). In particular, ruminant milk is rich in C18:2 cis-9,trans-11 CLA isomer, which is synthesized both in the rumen through the biohydrogenation of linoleic acid and in the mammary gland through the desaturation of transvaccenic acid C18:1 trans- 11 by $\Delta^{9}$-desaturase. The CLA content in cow milk can be manipulated by the diet. Vegetable oils rich in linolenic acid have been supplemented to dairy cows to enhance the milk content of C18:2 cis-9,trans-11 CLA (Zheng et al., 2005; Bu et al., 2007).

The aim of the study was to evaluate the effects of 2 different lipid supplementations (flaxseed vs. fish oil) 
Table 1. Ingredients, chemical composition, and $\mathrm{NE}_{\mathrm{L}}$ of the experimental diets (DM basis) ${ }^{1}$

\begin{tabular}{lrrr}
\hline Item & CT & FO & FS \\
\hline Concentrate $^{2}$ & 61.40 & 60.70 & 54.80 \\
Corn & 5.70 & 5.70 & 5.70 \\
Oat hays & 32.90 & 32.50 & 33.00 \\
Whole flaxseed & 0 & 0 & 6.50 \\
Fish oil & 0 & 1.10 & 0 \\
DM, \% & 92.04 & 92.00 & 92.26 \\
Ether extract, \% of DM & 3.23 & 3.46 & 5.31 \\
CP, \% of DM & 15.43 & 15.36 & 15.21 \\
ADF, \% of DM & 22.72 & 22.49 & 22.75 \\
NDF, \% of DM & 40.99 & 41.45 & 40.84 \\
ADL, \% of DM & 3.98 & 3.95 & 4.09 \\
NE, Mcal/kg & 1.68 & 1.69 & 1.65 \\
Fatty acids, \% of total of fatty acids & & & \\
C14:0 & 4.76 & 4.77 & 4.59 \\
C16:0 01.18 & 21.13 & 20.40 \\
C16:1 $18: 0$ & 0.78 & 0.85 & 0.76 \\
C18:1 cis-9 & 6.71 & 6.68 & 6.65 \\
C18:2 cis-9, cis-12 & 28.46 & 28.33 & 27.59 \\
C18: n-3 & 25.52 & 25.30 & 24.24 \\
C20:5n-3 & 3.90 & 3.87 & 7.01 \\
C22:6n-3 & 0 & 0.07 & 0 \\
\hline
\end{tabular}

${ }^{1} \mathrm{CT}=$ control group with no fat supplementation; $\mathrm{FO}=$ fat supplementation based on fish oil (Orovital Cod, Ascor Chimici srl, Capocolle di Bertinoro, Italy); FS = fat supplementation based on flaxseed (Lin Tech, Tecnozoo srl, Torreselle di Piombino Dese, Italy).

${ }^{2}$ Contained: corn meal, roasted soybean meal, wheat germ meal, wheat meal, roasted soybean seeds, barley meal, wheat fine bran, sugarcane molasses, partially debarked sunflower meal, calcium carbonate, calcium hydrogen phospate, sodium bicarbonate, sodium chloride, magnesium oxide, $40 \mathrm{IU} / \mathrm{g}$ of vitamin $\mathrm{A}, 4 \mathrm{IU} / \mathrm{g}$ of vitamin $\mathrm{D}_{3}, 0.004 \%$ vitamin $\mathrm{E}, 0.0005 \%$ vitamin $\mathrm{B}_{1}, 0.0002 \%$ vitamin $\mathrm{B}_{2}, 0.02 \%$ niacin, $0.05 \% \mathrm{Cl}, 0.003 \% \mathrm{Fe}, 0.00025 \%$ Co, $0.0006 \%$ I, $0.009 \% \mathrm{Mn}, 0.001 \%$ $\mathrm{Cu}, 0.025 \% \mathrm{Zn}$, and $0.00003 \% \mathrm{Se}$.

${ }^{3} \mathrm{ADL}=$ acid detergent lignin.

on milk composition and milk FA profile from cows during summer.

\section{MATERIALS AND METHODS}

\section{Animals, Experimental Design, and Dietary Treatments}

The experiment was conducted on a commercial farm located approximately $20 \mathrm{~km}$ north-east of Foggia, Apulia, Southern Italy (latitude $41^{\circ} 27^{\prime} 6^{\prime \prime}$, longitude $\left.15^{\circ} 33^{\prime} 5^{\prime \prime}\right)$. A 12 -wk trial was performed from June to September of 2006 with 24 Italian Friesian cows that were divided into 3 groups of 8 animals and blocked according to DIM $(100.11 \pm 3.79)$, parity $(2.46 \pm 0.26)$, milk yield $(24.37 \pm 0.36 \mathrm{~kg} / \mathrm{d})$, and milk fat $(3.77 \pm$ $0.13)$ and protein $(3.03 \pm 0.08)$ content. Treatments involved feeding diets with different type of fat supplementation. Experimental diets (Table 1) were 1) a control diet containing corn, oat hay, concentrate, and no supplemental fat (CT); 2) a diet containing $1.2 \mathrm{~kg} / \mathrm{d}$ of whole flaxseed in substitution of an equal amount of concentrate (FS); and 3) a diet containing $200 \mathrm{~g} / \mathrm{d}$ of microencapsulated fish oil in addition to CT $\operatorname{diet}(\mathbf{F O})$. Formulation and chemical composition of the diets are shown in Table 1. Cows were housed in tie stalls and water was available ad libitum. The diets were fed twice daily and each group of cows was fed separately. Cows in all groups completely consumed the daily ration given. The DMI was $16.57 \mathrm{~kg} / \mathrm{d}$ for CT cows, 16.75 $\mathrm{kg} / \mathrm{d}$ for FO cows, and $16.61 \mathrm{~kg} / \mathrm{d}$ for FS cows ( $\mathrm{SE} \pm$ $0.2 \mathrm{~kg} / \mathrm{d}$ ). The $\mathrm{NE}_{\mathrm{L}}$ of the diet was calculated by using NRC (2001) (Table1). Milking was carried out twice daily (0600 and $1700 \mathrm{~h}$ ) and milk yield was recorded every $14 \mathrm{~d}$. Environment temperature and humidity on the farm were monitored using TIG2-TH thermohygrographs (LSI, Settala Premenugo-Milan, Italy). The temperature-humidity index (THI) was calculated as proposed by Kelly and Bond (1971).

\section{Feed Sampling and Analysis}

The chemical composition of the diets was determined by standard procedures (AOAC, 1990; Table1). A representative sample of feed supplementation was collected for FA analysis of feed according to Sukhija and Palmquist (1988). The FA methyl esters (FAME) were analyzed on an Agilent 6890N gas chromatograph (Agilent Technologies, Santa Clara, CA). Separation of FAME was performed using a DB 23 fused-silica capillary column $(60 \mathrm{~m} \times 0.25 \mathrm{~mm}$ i.d, $0.25 \mu \mathrm{m}$ film thickness; Agilent Technologies). Operating conditions were as follows: helium flow-rate of $1.2 \mathrm{~mL} / \mathrm{min}$, flame ionization detector (FID) at $250^{\circ} \mathrm{C}$, a split-splitless injector at $240^{\circ} \mathrm{C}$, and an injection volume of $1 \mu \mathrm{L}$ with a split ratio 1:50. The initial column temperature was set at $60^{\circ} \mathrm{C}$, increased to $180^{\circ} \mathrm{C}$ at $25^{\circ} \mathrm{C} / \mathrm{min}$, and finally increased to $230^{\circ} \mathrm{C}$ at $6^{\circ} \mathrm{C} / \mathrm{min}$ and held for $15 \mathrm{~min}$. Individual FAME peaks were identified using standards from Matreya (Matreya LLC, Pleasant Gap, PA). Each FA was reported as a percentage of FAME (Table 1).

\section{Milk Sampling and Analysis}

Milk samples from each cow were collected at morning and afternoon milkings every $14 \mathrm{~d}$ for the duration of the 12-wk treatment period. One aliquot was stored at $-20^{\circ} \mathrm{C}$ for FA analysis. Fresh samples were used for chemical analysis consisting of the following measurements: evaluation of $\mathrm{pH}$ (GLP 21 Crison, Spain), total protein, $\mathrm{CN}$, fat, and lactose content using an infrared spectrophotometer (MilkoScan 133B, Foss Electric, Hillerød, Denmark) according to the IDF (1990) standard; evaluation of SCC using a Foss Electric Fossomatic 90 cell counter (IDF, 1995); and evaluation of the renneting characteristics (clotting time, rate of clot 
formation, and clot firmness after $30 \mathrm{~min}$ ) using a Foss Electric formagraph. The milk coagulating index was calculated as the clot firmness to clotting time + rate of clot formation ratio. Milk energy output was calculated according to the formula of Crovetto and van der Honing (1984).

For the analysis of milk FA, milk fat was extracted according to the procedure of Luna et al. (2005) and transesterification of FA according to ISO-IDF (2002) procedures. Fatty acid methyl esters were separated and measured using a gas chromatograph (Agilent 6890N) equipped with CP-Sil 88 fused-silica capillary column $(100 \mathrm{~m} \times 0.25 \mathrm{~mm}$ i.d.; $0.25 \mu \mathrm{m}$ film thickness $)$. Operating conditions were as follows: a helium flow-rate of 1 $\mathrm{mL} / \mathrm{min}$, a flame ionization detector at $260^{\circ} \mathrm{C}$, a splitsplitless injector at $260^{\circ} \mathrm{C}$, and an injection volume of $1 \mu \mathrm{L}$ with a split ratio $1: 50$. The temperature program of the column was set at $100^{\circ} \mathrm{C}$ and subsequently increased to $240^{\circ} \mathrm{C}$ at $3.5^{\circ} \mathrm{C} / \mathrm{min}$ and held for $15 \mathrm{~min}$. Each peak was identified using standard from Matreya (Matreya LLC). Fatty acids were reported as g/100 g of FAME total and saturated FA, monounsaturated FA, and PUFA were calculated. The desaturase indices were calculated as described by Kelsey et al. (2003). Atherogenic and thrombogenic indices were calculated according to Ulbricht and Southgate (1991).

\section{Statistical Analysis}

All variables were tested for normality using the Shapiro-Wilk test (Shapiro and Wilk, 1965) and transformed into logarithm form to normalize their frequency distribution, when necessary. Then, data were processed by ANOVA using the GLM procedure of SAS (SAS Institute, 1999) for repeated measures. The variation attributable to the fat supplementation was tested. The variation attributable to fat supplementation, time of sampling, and their interactions was tested for milk, protein, and fat yield and milk energy output. Individual animal variation within treatment was used as the error term. When significant effects were found (at $P<0.05$ ), Student's $t$-test was used to locate significant differences between means.

\section{RESULTS}

\section{Environmental Conditions}

Temporal variations of maximum, minimum, and mean THI during the 12-wk treatment period are shown in Figure 1. The mean THI value registered during the study period was $76.1 \pm 3.1$, and the average of the maximum THI values was of $86.0 \pm 3.1$. The variations of THI registered were the results of high relative humidity values, which reached $91 \%$ as average of the maximum values. In particular, the highest minimum value of THI was $70.60 \pm 2.67$ and was registered during wk 10 of the trial. Mean THI values ranged from $71.18 \pm 4.76$ to $80.21 \pm 2.06$, and maximum THI values ranged from $82.22 \pm 3.26$ to $90.31 \pm 4.52$.

\section{Milk Yield and Milk Composition}

No significant differences were found for milk yield among groups even if milk yield was numerically higher in milk from FS cows than in milk from CT cows $(24.00$ vs. $22.45 \pm 0.87 \mathrm{~kg} / \mathrm{d}$; Table 2). Protein and $\mathrm{CN}$ yields were significantly higher in milk of FS cows than in milk of FO and $\mathrm{CT}$ cows $(P<0.01)$. In addition, protein yield was affected by time of sampling $(P<0.01)$. A reduction in milk protein yield was found in CT cows compared with FS cows at wk 10 of the experiment $(P$ $<0.1$; Figure 2). Flaxseed supplementation positively affected the milk fat percentage and milk fat yields ( $P<0.05$ and $P<0.01$, respectively). In particular, milk fat content of FS cows was $10 \%$ higher than milk fat content of CT cows and $12 \%$ higher than milk fat content of FO cows. Milk fat yield in FS cows was 21 and $17 \%$ higher than milk fat yield in $\mathrm{CT}$ and FO cows, respectively. An effect of time of sampling for milk fat yield was found $(P<0.001)$. At wk 10 of the trial, FS cows displayed higher fat yield than $\mathrm{CT}$ and FO cows $(P<0.1$; Figure 3$)$. No significant differences for protein, $\mathrm{CN}$, and lactose contents, milk SCC, and renneting parameters were observed among treatments (data not shown). Milk energy output was affected by fat supplementation $(P<0.05)$. The FS cows had higher milk energy output $(3.05 \pm 0.06 \mathrm{MJ} / \mathrm{kg})$ than both the $\mathrm{CT}$ and FO cows $(2.85 \pm 0.06$ and $2.86 \pm 0.06 \mathrm{MJ} / \mathrm{kg}$, respectively).

\section{Milk FA Composition}

The effect of the experimental diet on FA composition and nutritional indices of milk are shown in Tables 3 and 4. Supplementation with flaxseed and fish oil significantly affected milk FA profile. The content of C4:0 in milk from FS cows was lower $(P<0.05)$ than in milk from $\mathrm{FO}$ cows, whereas no differences emerged among treatments for the content of FA C6:0 to C12:0. Milk from FS cows resulted in lower C14:0 content than milk from CT cows $(P<0.05)$ and lower C15:0, C16:0, C17:0, and C17:1 contents than milk from CT and FO cows $(P<0.001)$. The $\mathrm{C} 18: 0$ and $\mathrm{C} 18: 1$ cis-9 contents were higher $(P<0.01)$ in the milk of FS cows than in the milk of FO and CT cows. Dietary supplementations increased contents of milk C18:1 trans-11 $(P<0.01)$ and C18:2 cis-9,trans-11 CLA isomer $(P<0.001)$ when 
Table 2. Least squares means \pm SEM of milk yield and composition of cows fed the experimental $\operatorname{diets}^{1}$

\begin{tabular}{lccccc}
\hline & \multicolumn{3}{c}{ Treatment } & & \\
\cline { 2 - 3 } Item & CT & FO & FS & SEM & Effect, $P$-value \\
\hline Yield, kg/d & & & & \\
Milk & 22.45 & 23.04 & 24.00 & 0.87 & NS \\
Fat & $0.79^{\mathrm{b}}$ & $0.82^{\mathrm{b}}$ & $0.96^{\mathrm{a}}$ & 0.03 & $* *$ \\
Protein & $0.68^{\mathrm{b}}$ & $0.7^{\mathrm{b}}$ & $0.78^{\mathrm{a}}$ & 0.02 & $* *$ \\
CN & $0.54^{\mathrm{b}}$ & $0.55^{\mathrm{b}}$ & $0.62^{\mathrm{a}}$ & 0.02 & $* *$ \\
Milk composition, $\%$ & & & & $*$ \\
Fat & $3.62^{\mathrm{b}}$ & $3.56^{\mathrm{b}}$ & $3.99^{\mathrm{a}}$ & 0.13 & NS \\
Protein & 3.07 & 3.08 & 3.25 & 0.08 & NS \\
CN & 2.42 & 2.42 & 2.59 & 0.06 & NS \\
Lactose & 4.79 & 4.75 & 4.85 & 0.04 & NS \\
pH & 6.63 & 6.63 & 6.62 & 0.02 & NS \\
SCC, $\log _{10}$ cells $/ \mathrm{mL}$ & 4.99 & 5.03 & 5.34 & 0.18 & \\
\hline
\end{tabular}

${ }^{\mathrm{a}, \mathrm{b}}$ Means in the same row with different superscripts differ $(P<0.05)$.

${ }^{1} \mathrm{CT}=$ control group with no fat supplementation; $\mathrm{FO}=$ fat supplementation based on fish oil (Orovital Cod, Ascor Chimici srl, Capocolle di Bertinoro, Italy); FS = fat supplementation based on flaxseed (Lin Tech, Tecnozoo srl, Torreselle di Piombino Dese, Italy).

${ }^{*} P<0.05 ;{ }^{* *} P<0.01$.

compared with the $\mathrm{CT}$ diet. In addition, the content of the C18:2 cis-9,trans-11 CLA isomer was higher in milk from FS cows than in milk from FO cows. On the other hand, milk from FO cows had a higher C18:2 trans10, cis-12 content than milk from FS and CT cows $(P<$ 0.001). As expected, dietary supplementation increased $(P<0.001)$ the content of $\mathrm{n}-3$ PUFA in milk fat compared with CT milk fat, even if milk from FO cows showed higher n-3 PUFA content than milk from FS cows. In particular, $\alpha$-linolenic acid (C18:3n-3) content was higher $(P<0.05)$ in milk from FO cows than in milk from CT cows. Moreover, the C18:3n-3 content of milk accounted for about $81 \%$ of the total n-3 PUFA in FO milk and for $98 \%$ in FS milk. The remaining $19 \%$ of the total n-3 PUFA in FO milk consisted of C20:3n-3, C20:5n-3, and C22:6n-3, the contents of which were the highest in FO milk $(P<0.001)$. Content of $\mathrm{C} 20$ :3n-6 was higher in $\mathrm{CT}$ milk than in FO milk $(P<0.05)$. The total n-6 PUFA content was higher in FS milk than in FO and CT milk $(P<0.05)$. The FS cows produced the milk with the lowest saturated $(P<0.01)$ and the highest monounsaturated $(P<0.05)$ FA contents and the highest total CLA content $(P<0.001)$ compared with CT and FO cows. The total CLA content of FO

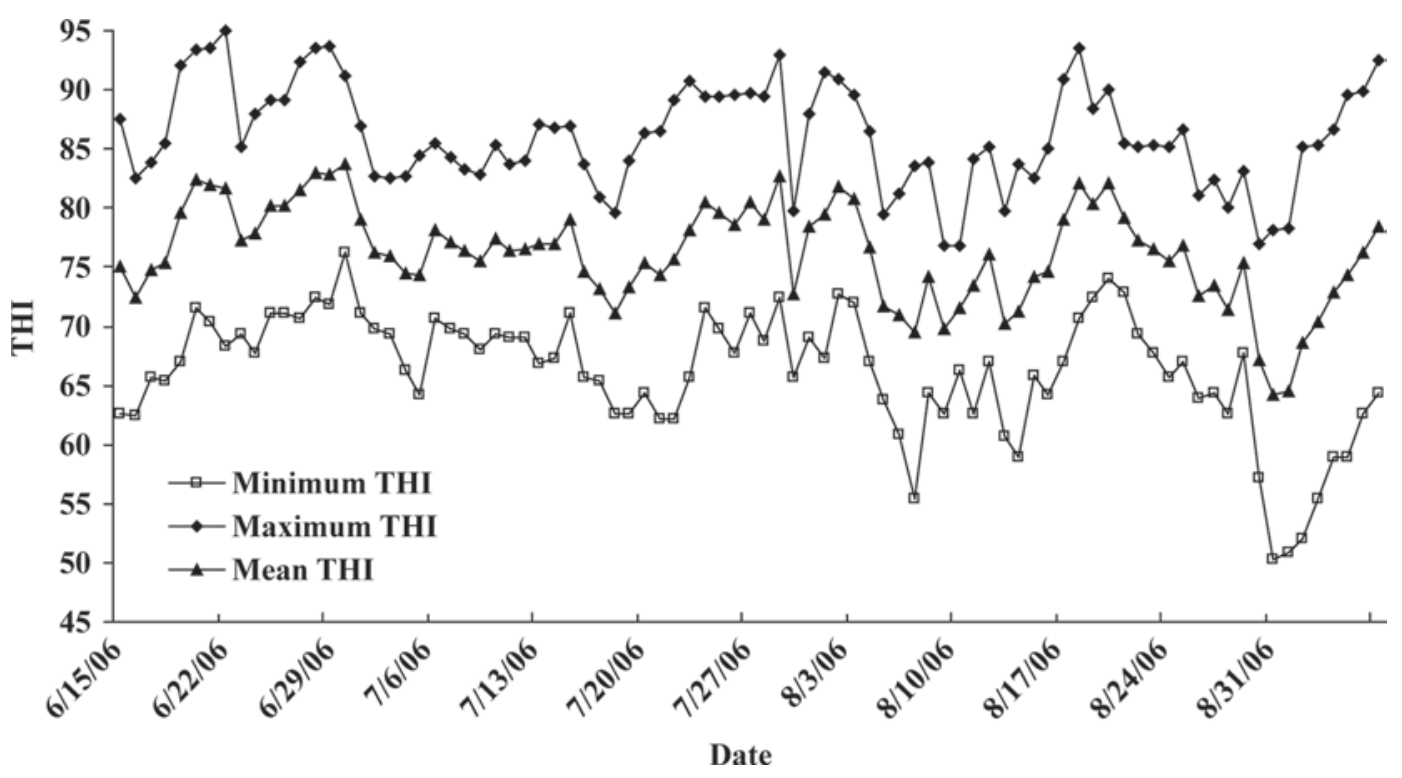

Figure 1. Daily averages of temperature-humidity index (THI) values (minimum, maximum, and mean) detected during the days of the experimental period, calculated using the formula of Kelly and Bond (1971). 


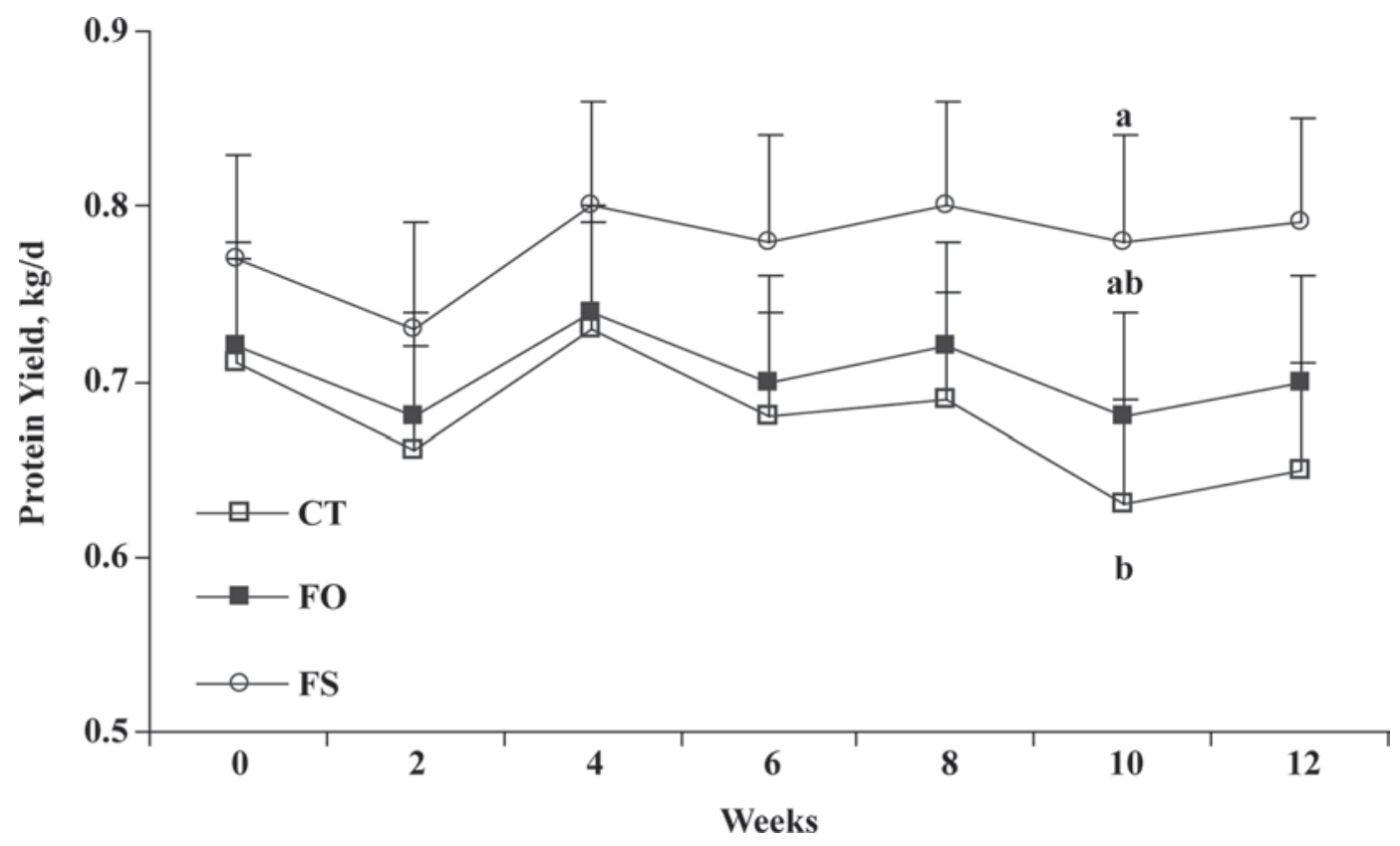

Figure 2. Milk protein yield (LSM \pm SEM) measured in cows fed control diet (CT), fish oil (FO), or flaxseed (FS) at the beginning of the trial (wk 0) and then at 2, 4, 6, 8, 10, and 12 wk of the trial. Values with different letters differ between feeding treatments within a sampling day $(P<0.1)$.

milk was, in turn, higher than that of CT milk. Polyunsaturated FA significantly increased $(P<0.05)$ when cows were fed FS and FO diets. We calculated the 4 major products of $\Delta^{9}$-desaturase activity in the mammary gland. The $\Delta^{9}$-desaturase indexes for $\mathrm{C} 14: 1$ cis-9/
C14:0, C16:1 cis-9/C16:0, and C18:1 cis-9/C18:0 were not different among treatments (Table 4). The FS diet increased the C18:2 cis-9,trans-11/C18:1 trans-11 $\Delta^{9}$ desaturase index $(P<0.001)$ compared with FO and $\mathrm{CT}$ diets. In addition, milk from FO cows showed higher

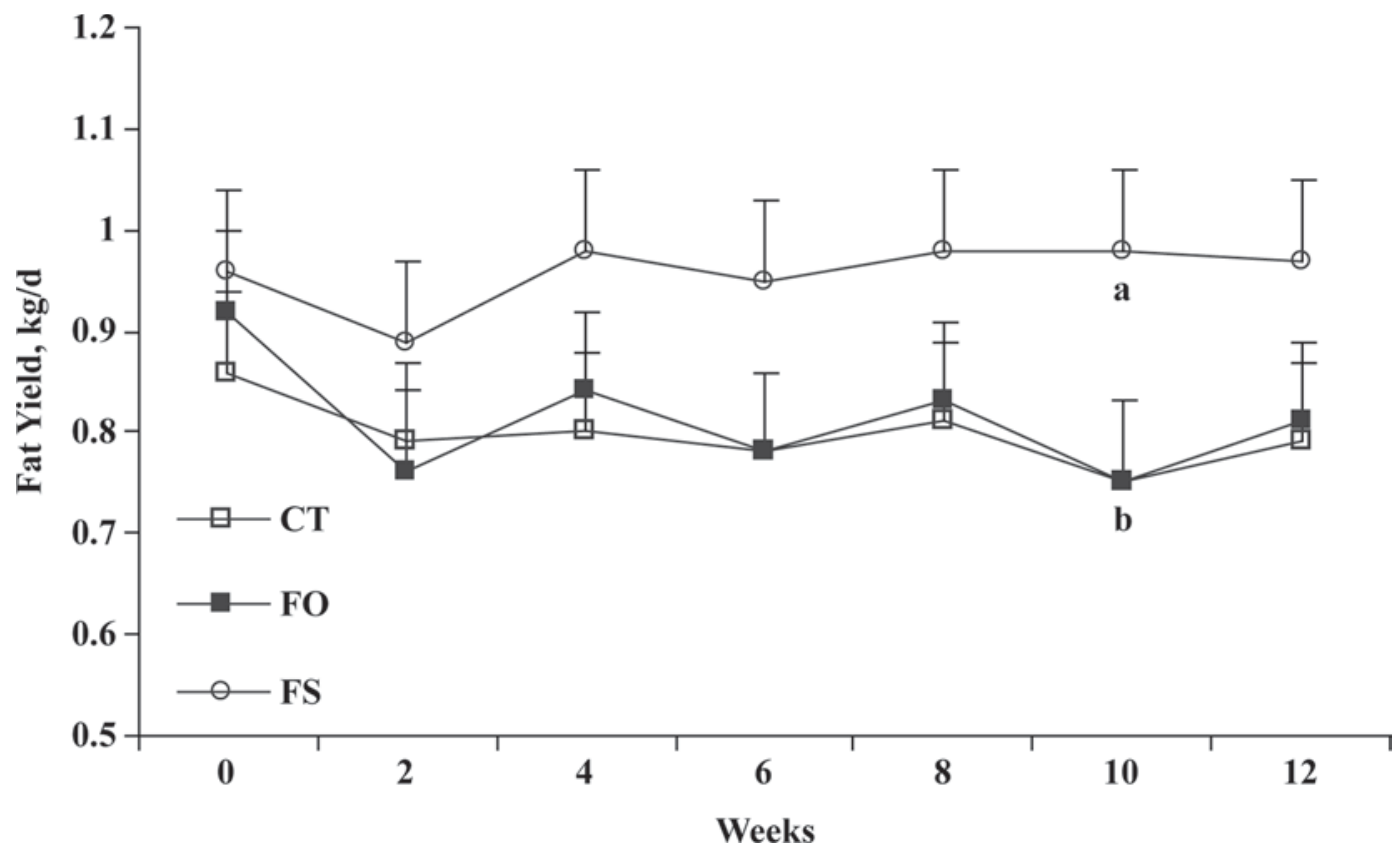

Figure 3. Milk fat yield ( $\mathrm{LSM} \pm \mathrm{SEM})$ measured in cows fed control diet (CT), fish oil (FO), or flaxseed (FS) at the beginning of the trial (wk 0) and then at $2,4,6,8,10$, and 12 wk of the trial. Values with different letters differ between feeding treatments within a sampling day $(P<0.1)$. 
Table 3. Least squares means \pm SEM and sums of fatty acid composition ( $\mathrm{g} / 100 \mathrm{~g}$ of total fatty acids) of milk from cows fed the experimental $\operatorname{diets}^{1}$

\begin{tabular}{|c|c|c|c|c|c|}
\hline \multirow[b]{2}{*}{ Fatty acid } & \multicolumn{3}{|c|}{ Treatment } & \multirow[b]{2}{*}{ SEM } & \multirow[b]{2}{*}{ Effect, $P$-value } \\
\hline & $\mathrm{CT}$ & $\mathrm{FO}$ & FS & & \\
\hline $\mathrm{C} 4: 0$ & $5.45^{\mathrm{ab}}$ & $5.55^{\mathrm{a}}$ & $5.23^{\mathrm{b}}$ & 0.083 & $*$ \\
\hline C6:0 & 2.86 & 2.85 & 2.79 & 0.36 & NS \\
\hline $\mathrm{C} 8: 0$ & 1.49 & 1.43 & 1.44 & 0.036 & NS \\
\hline C10:0 & 2.93 & 2.68 & 2.77 & 0.112 & NS \\
\hline $\mathrm{C} 12: 0$ & 3.09 & 2.82 & 2.87 & 0.12 & NS \\
\hline C14:0 & $10.96^{\mathrm{a}}$ & $10.68^{\mathrm{ab}}$ & $10.14^{\mathrm{b}}$ & 0.27 & * \\
\hline C14:1 cis-9 & 0.59 & 0.60 & 0.56 & 0.0019 & NS \\
\hline C15:0 & $0.93^{\mathrm{a}}$ & $0.93^{\mathrm{a}}$ & $0.83^{\mathrm{b}}$ & 0.018 & $* * *$ \\
\hline $\mathrm{C} 16: 0$ & $25.81^{\mathrm{a}}$ & $26.31^{\mathrm{a}}$ & $23.74^{\mathrm{b}}$ & 0.42 & $* * *$ \\
\hline C16:1 cis-9 & 1.21 & 1.29 & 1.08 & 0.072 & NS \\
\hline C17:0 & $0.45^{\mathrm{a}}$ & $0.47^{\mathrm{a}}$ & $0.38^{\mathrm{b}}$ & 0.01 & $* * *$ \\
\hline $\mathrm{C} 17: 1$ & $0.163^{\mathrm{a}}$ & $0.176^{\mathrm{a}}$ & $0.13^{\mathrm{b}}$ & 0.0051 & *** \\
\hline C18:0 & $11.50^{\mathrm{b}}$ & $11.48^{\mathrm{b}}$ & $13.20^{\mathrm{a}}$ & 0.36 & $* *$ \\
\hline $\mathrm{C} 20: 0$ & $0.090^{\mathrm{b}}$ & $0.16^{\mathrm{a}}$ & $0.080^{\mathrm{c}}$ & 0.003 & $* * *$ \\
\hline C20:1 & $0.24^{\mathrm{a}}$ & $0.25^{\mathrm{a}}$ & $0.113^{\mathrm{b}}$ & 0.005 & $* * *$ \\
\hline C18:1 trans -9 & 0.662 & 0.66 & 0.69 & 0.018 & NS \\
\hline $\mathrm{C} 18: 1$ trans -11 & $1.82^{\mathrm{b}}$ & $2.00^{\mathrm{a}}$ & $2.05^{\mathrm{a}}$ & 0.041 & $* *$ \\
\hline C18:1 cis-9 & $25.43^{\mathrm{b}}$ & $24.90^{\mathrm{b}}$ & $27.05^{\mathrm{a}}$ & 0.43 & $* *$ \\
\hline $\mathrm{C} 18: 2$ trans -9, trans- 12 & $0.06^{\mathrm{b}}$ & $0.038^{\mathrm{c}}$ & $0.126^{\mathrm{a}}$ & 0.004 & $* * *$ \\
\hline $\mathrm{C} 18: 2$ cis- 9 , cis- 12 & 2.74 & 2.78 & 2.56 & 0.09 & NS \\
\hline $\mathrm{C} 18: 2$ cis-9,trans-11 & $0.37^{\mathrm{c}}$ & $0.45^{\mathrm{b}}$ & $0.87^{\mathrm{a}}$ & 0.013 & $* * *$ \\
\hline $\mathrm{C} 18: 2$ trans- 10, cis- 12 & $0.13^{\mathrm{b}}$ & $0.154^{\mathrm{a}}$ & $0.123^{\mathrm{b}}$ & 0.0023 & $* * *$ \\
\hline C18:3n-3 & $0.75^{\mathrm{b}}$ & $0.84^{\mathrm{a}}$ & $0.81^{\mathrm{ab}}$ & 0.021 & $*$ \\
\hline$C 20: 3 n-3$ & $0.001^{\mathrm{b}}$ & $0.0189^{\mathrm{a}}$ & $0.001^{\mathrm{b}}$ & 0.0017 & $* * *$ \\
\hline C20:5n-3 & $0.003^{\mathrm{c}}$ & $0.0601^{\mathrm{a}}$ & $0.022^{\mathrm{b}}$ & 0.0023 & $* * *$ \\
\hline $\mathrm{C} 22: 6 \mathrm{n}-3$ & $0.001^{\mathrm{b}}$ & $0.1172^{\mathrm{a}}$ & $0.001^{\mathrm{b}}$ & 0.004 & $* * *$ \\
\hline $\mathrm{C} 20: 3 \mathrm{n}-6$ & $0.098^{\mathrm{a}}$ & $0.059^{\mathrm{b}}$ & $0.08^{\mathrm{ab}}$ & 0.0086 & $*$ \\
\hline $\mathrm{C} 20: 4 \mathrm{n}-6$ & 0.1400 & 0.135 & 0.124 & 0.006 & NS \\
\hline$\Sigma$ Conjugated linoleic acid & $0.50^{\mathrm{c}}$ & $0.60^{\mathrm{b}}$ & $1.00^{\mathrm{a}}$ & 0.013 & $* * *$ \\
\hline$\Sigma$ Saturated fatty acids & $65.58^{\mathrm{a}}$ & $65.37^{\mathrm{a}}$ & $63.47^{\mathrm{b}}$ & 0.45 & $* *$ \\
\hline$\Sigma$ Monounsaturated fatty acids & $30.13^{\mathrm{b}}$ & $29.88^{\mathrm{b}}$ & $31.68^{\mathrm{a}}$ & 0.43 & $*$ \\
\hline$\Sigma$ Polyunsaturated fatty acids & $4.30^{\mathrm{b}}$ & $4.65^{\mathrm{a}}$ & $4.72^{\mathrm{a}}$ & 0.1 & $*$ \\
\hline$\Sigma \mathrm{n}-3$ & $0.76^{\mathrm{c}}$ & $1.043^{\mathrm{a}}$ & $0.83^{\mathrm{b}}$ & 0.23 & $* * *$ \\
\hline$\Sigma \mathrm{n}-6$ & $3.54^{\mathrm{b}}$ & $3.61^{\mathrm{b}}$ & $3.89^{\mathrm{a}}$ & 0.07 & * \\
\hline
\end{tabular}

${ }^{a-c}$ Means in the same row with different superscripts differ $(P<0.05)$.

${ }^{1} \mathrm{CT}=$ control group with no fat supplementation; FO = fat supplementation based on fish oil (Orovital Cod, Ascor Chimici srl, Capocolle di Bertinoro, Italy); FS = fat supplementation based on flaxseed (Lin Tech, Tecnozoo srl, Torreselle di Piombino Dese, Italy).

${ }^{*} P<0.05 ;{ }^{*} P<0.01 ;{ }^{* * *} P<0.001$

C18:2 cis-9,trans-11/C18:1 trans-11 $\Delta^{9}$-desaturase index than milk from CT cows. Our results showed that flaxseed supplementation increased of $57 \%$ the mammary gland $\Delta^{9}$-desaturase activity for CLA synthesis. The atherogenic index was the lowest in FS milk and thrombogenic index was lower in FS milk than in CT milk $(P<0.05)$.

\section{DISCUSSION}

In dairy cows the physiological responses to high ambient temperature involve the reduction of milk production and feed intake. Armstrong (1994) suggested that the THI value of 72 can be considered the end of the comfort zone for lactating cows and found that milk production decreases after 72 . As expected, when the minimum THI averaged 70 and the mean THI averaged 79.5 , a reduction in milk yield was found. Fat supplementation to dairy cows has been considered a beneficial strategy to minimize the negative effects of high ambient temperatures on energy balance and nutrient intake (Knapp and Grummer, 1991). Milk production does not always positively respond to supplemental fat (Chan et al., 1997; Drackley et al., 2003; Moore et al., 2005; Rego et al., 2005). The failure to find a direct effect of fat supplementation on milk yield in previous trials could depend on several factors, including the source of fat and the level of supplementation. The effects of flaxseed supplementation on protein yield are conflicting (Ward et al., 2002; Petit, 2003; Gonthier et al., 2005). Results obtained in this experiment suggest that whole flaxseed supplementation during summer 
Table 4. Least squares means \pm SEM of desaturase and nutritional indices of milk from cows fed the experimental diets ${ }^{1}$

\begin{tabular}{|c|c|c|c|c|c|}
\hline \multirow[b]{2}{*}{ Item } & \multicolumn{3}{|c|}{ Treatment } & \multirow[b]{2}{*}{ SEM } & \multirow[b]{2}{*}{ Effect, $P$-value } \\
\hline & $\mathrm{CT}$ & $\mathrm{FO}$ & FS & & \\
\hline \multicolumn{6}{|l|}{ Desaturase indices $^{2}$} \\
\hline C14:1 cis-9 & 0.052 & 0.053 & 0.053 & 0.0018 & NS \\
\hline $\mathrm{C} 16: 1$ cis-9 & 0.045 & 0.047 & 0.043 & 0.0023 & NS \\
\hline C18:1 cis-9 & $0.69^{\mathrm{a}}$ & $0.68^{\mathrm{ab}}$ & $0.67^{\mathrm{b}}$ & 0.0052 & NS \\
\hline Conjugated linoleic acid & $0.170^{\mathrm{c}}$ & $0.187^{\mathrm{b}}$ & $0.294^{\mathrm{a}}$ & 0.0043 & $* * *$ \\
\hline \multicolumn{6}{|l|}{ Nutritional indices $^{3}$} \\
\hline Atherogenic index & $2.119^{\mathrm{a}}$ & $2.093^{\mathrm{b}}$ & $1.859^{\mathrm{c}}$ & 0.62 & $*$ \\
\hline Thrombogenic index & $2.50^{\mathrm{a}}$ & $2.41^{\mathrm{ab}}$ & $2.31^{\mathrm{b}}$ & 0.046 & $*$ \\
\hline
\end{tabular}

${ }^{\mathrm{a}-\mathrm{c}}$ Means in the same row with different superscripts differ $(P<0.05)$.

${ }^{1} \mathrm{CT}=$ control group with no fat supplementation; FO $=$ fat supplementation based on fish oil (Orovital Cod, Ascor Chimici srl, Capocolle di Bertinoro, Italy); FS = fat supplementation based on flaxseed (Lin Tech, Tecnozoo srl, Torreselle di Piombino Dese, Italy).

${ }^{2}$ Desaturase indices are ratio of the $\Delta^{9}$-desaturase product divided by the sum of the $\Delta^{9}$-desaturase product and substrate as described by Kelsey et al. (2003). For example, the desaturase index for C14:1 cis-9 would be (C14:1 cis-9)/(C14:1 cis-9 + C14:0).

${ }^{3}$ Atherogenic and thrombogenic indexes were calculated using Ulbricht and Southgate's (1991) formulas: atherogenic index $=(\mathrm{C} 12: 0+4 \times \mathrm{C} 14: 0+\mathrm{C} 16: 0) /[\Sigma$ monounsaturated fatty acids $+\Sigma$ polyunsaturated fatty acids $(\mathrm{n}-6)+(\mathrm{n}-3)]$; thrombogenic index $=(\mathrm{C} 14: 0+\mathrm{C} 16: 0+\mathrm{C} 18: 0) /[5.0 \times \Sigma$ monounsaturated fatty acids + $0.5 \times \Sigma$ polyunsaturated fatty acids $(\mathrm{n}-6)+3 \times \Sigma$ polyunsaturated fatty acids $(\mathrm{n}-3)+(\mathrm{n}-3) /(\mathrm{n}-6)]$.

$* P<0.05 ; * * * P<0.001$

months may have a positive influence on milk protein synthesis, given that milk yield increased by $7 \%$ and protein and $\mathrm{CN}$ yield by $15 \%$ in milk from FS cows compared with milk from CT cows. The increase in milk protein yield could be the result of a decrease in the ruminal protein degradability of the whole flaxseed supplemented. The administration of whole flaxseed could have increased the flow of $\mathrm{N}$ to the duodenum because of its greater bypass protein content. As a consequence, the AA availability for protein synthesis in the mammary gland increased. Ikwuegbu and Sutton (1982) reported that protein digestion in the rumen decreased and $\mathrm{N}$ flow to the duodenum increased when linseed oil was infused in sheep rumen because of a reduction in rumen fauna.

High ambient temperature during summer months has been associated with depression in milk fat percentage (Moody et al., 1967). On the other hand, fat supplementation can also induce milk depression (reviewed by Bauman et al., 2001). In the current study, the increase in milk fat of FS cows was expected, given that they received about $2 \%$ more dietary fat than $\mathrm{CT}$ and $\mathrm{FO}$ cows. However, diets had a very similar $\mathrm{NE}_{\mathrm{L}}$ and flaxseed supplementation also improved the fat yield through a more increased, although not different, milk yield in FS cows. Indeed, flaxseed supplementation improved energy utilization for milk synthesis compared with FO and CT diets, as shown by milk energy output. In addition, flaxseed supplementation maintained fat yield unchanged throughout the trial; on the contrary, a reduction of fat yield in CT and FO cows was found with the increase in THI. Fish oil supplementation did not positively affect milk yield and composition of experimental cows. The effects of fish oil supplementation on milk yield and quality depend on different doses. Previous findings stated that fish oil supplementation reduced both protein and $\mathrm{CN}$ yields and contents of milk when administrated in doses of $300 \mathrm{~mL} / \mathrm{d}$ or higher (Chilliard and Doreau, 1997; Lacasse et al., 2002).

The main aim of this work was to evaluate the effect of different lipid sources on milk FA profile from cows under hot conditions. Several feeding strategies have been studied that aim to reduce the concentration of saturated FA and increase the concentration of PUFA in milk (Mustafa et al., 2003; Sarrazin et al., 2004). Milk from cows receiving flaxseed supplementation displayed an improvement in the FA profile, with an increase in the PUFA and monounsaturated FA content and a decrease in saturated FA content. These results are in agreement with recent studies (Ward et al., 2002; Mustafa et al., 2003; Soita et al., 2003; Gonthier et al., 2005), which reported similar changes in milk fat when flaxseed supplements were used. In particular, in the present study the decrease in $\mathrm{C} 14: 0$ and C16:0 contents in milk from FS cows may be a positive goal from a human health perspective because high proportions of $\mathrm{C} 14: 0$ and $\mathrm{C} 16: 0$ has been associated with human cardiovascular problems (Noakes et al., 1996). 
The increased content of C18 FA in the milk fat of cows fed the flaxseed diet has been reported by several authors (Mustafa et al., 2003; Loor et al., 2005). The increase of $\mathrm{C} 18: 1$ can be the result of partial biohydrogenation of $\mathrm{C} 18: 2$ and $\mathrm{C} 18: 3 \mathrm{FA}$ and of the desaturation of C18:0 in the mammary gland (Kennelly, 1996). On the other hand, the reduced content of stearic acid observed in milk from cows fed fish oil could be ascribed to a reduced biohydrogenation in the rumen of C18:1 to C18:0. This may account for the reduced C18:1 cis-9 content of milk from FO cows as well as the reduced milk fat synthesis compared with FS cows. Several studies supported the hypothesis that fish oil can induce milk fat depression by acting on the reduction of C18:0 availability (Chilliard et al., 2001; Loor et al., 2005). The increased dietary intake of C18:3 in flaxseed-supplemented cows resulted in increased levels of C18:1 trans-11 and increased CLA C18:2 cis-9,trans-11 by $\Delta^{9}$-desaturase activity. Fish oil supplementation also resulted in increased levels of milk C18:1 trans-11 even though a proportional increase in C18:2 cis-9,trans-11 did not emerge. On the contrary, Shingfield et al. (2003) reported that feeding fish oil enhanced C18:2 cis-9,trans-11 content as a consequence of the increased supply of C18:1 trans-11. The endogenous synthesis of CLA C18:2 cis-9,trans-11 by $\Delta^{9}$-desaturase of the mammary gland is strictly connected to C18:1 trans- 11 content of milk, and previous studies stated that milk with high CLA content also had high C18:1 trans-11 content (Griinari et al., 2000). The reduced activity of $\Delta^{9}$-desaturase in the mammary gland of fish oil-supplemented cows could be the result of fish oil-derived FA that may reduce $\Delta^{9}$-desaturase activity by decreasing $\Delta^{9}$-desaturase mRNA abundance of the mammary gland (Ahnadi et al., 1998; Chilliard et al., 2001). In addition, Baumgard et al. (2000) demonstrated that in dairy cows the C18:2 trans-10,cis-12 CLA isomer can inhibit the $\Delta^{9}$-desaturase of the mammary gland. The high levels of C18:2 trans-10,cis-12 together with the reduced levels of $\Delta^{9}$-desaturase activity detected in milk from FO cows suggest that the C18:2 trans-10, cis-12 CLA isomer is the main fish oil-derived FA responsible for the reduced desaturation of C18:1 trans-11 in C18:2 cis-9,trans-11. As a result, the total CLA content was $100 \%$ higher in milk from FS cows than in milk from $\mathrm{CT}$ cows and $67 \%$ higher in milk from FS cows than in milk from FO cows. Feeding flaxseed under hot climate could be considered a more efficient method to increase CLA concentrations in milk than feeding fish oil

As expected, the content of n-3 PUFA was $37 \%$ higher in milk from $\mathrm{FO}$ cows than in milk from $\mathrm{CT}$ cows. In particular, the higher EPA (C20:5n-3) and DHA (C22:6n-3) content in milk from FO cows reflects the FA composition of the fish oil supplement.
Milk from FS cows together with the high CLA content was characterized by low atherogenic and thrombogenic indices, suggesting that its utilization has less detrimental effects concerning the atherosclerosis and coronary thrombosis risk associated with the consumption of milk and dairy products, being potentially healthier for humans.

\section{CONCLUSIONS}

Feeding flaxseed in summer can be considered a strategy to increase both fat content and yield together with the protein and $\mathrm{CN}$ yield of milk. In addition, flaxseed supplementation improved FA profile and the CLA content of milk. On the other hand, fish oil supplementation enhanced n-3 PUFA, EPA, and DHA contents of milk. Results demonstrate that flaxseed supplementation improves composition and nutritional properties of milk from cows produced during summer months. In addition, flaxseed supplementation to dairy cows can contribute to improve the healthy properties of milk, enhancing the CLA content of milk and suggesting that its consumption benefits human health.

\section{ACKNOWLEDGMENTS}

Research supported by the Italian Ministero dell'Università e della Ricerca Scientifica (PRIN 2005; Rome, Italy). The authors acknowledge Concetta Perilli and Stefano D'urso (Dipartimento PRIME, Università di Foggia, Foggia, Italy) for expert technical assistance.

\section{REFERENCES}

Ahnadi, C. E., N. Beswick, J. J. Kennelly, and P. Lacasse. 1998. Effect on mammary lipid metabolism. J. Anim. Sci. 76(Suppl. 1):232.

AOAC. 1990. Official Methods of Analysis. Vol. I. 15th ed. Association of Official Analytical Chemists, Arlington, VA.

Armstrong, D. V. 1994. Heat stress interaction with shade and cooling. J. Dairy Sci. 77:2044-2050.

Bauman, D. E., B. A. Corl, L. H. Baumgard, and J. M. Griinari. 2001. Conjugated linoleic acid (CLA) and the dairy cow. Pages 221-250 in Recent Advances in Animal Nutrition 2001. P. C. Garnsworthy and J. Wiseman, ed. Nottingham University Press, Nottingham, UK.

Baumgard, L. H., B. A. Corl, D. A. Dwyer, A. Saebo, and D. E. Bauman. 2000. Identification of the conjugated linoleic acid isomer that inhibits milk fat synthesis. Am. J. Physiol. 278:R179-R184.

Bu, D. P., J. Q. Wang, T. R. Dhiman, and S. J. Liu. 2007. Effectiveness of oils rich in linoleic and linolenic acids to enhance conjugated linoleic acid in milk from dairy cows. J. Dairy Sci. 90:998-1007.

Chan, S. C., J. T. Huber, K. H. Chen, J. M. Simas, and Z. Wu. 1997. Effects of ruminally inert fat and evaporative cooling on dairy cows in hot environmental temperatures. J. Dairy Sci. 80:1172-1178.

Chilliard, Y., and M. Doreau. 1997. Effects of ruminal or postruminal fish oil supply on cow milk yield and composition. Reprod. Nutr. Dev. 37:338-339.

Chilliard, Y., A. Ferlay, and M. Doreau. 2001. Effect of different types of forages, animal fat or marine oils in cow's diet on milk fat secretion 
and composition, especially conjugated linoleic acid (CLA) and polyunsaturated fatty acids. Livest. Prod. Sci. 70:31-48.

Crovetto, G. M., and Y. van der Honing. 1984. Prediction of the energy content of milk from Friesian and Jersey cows with normal and high fat concentration. J. Anim. Physiol. Anim. Nutr. (Berl.) 51:88-97.

Drackley, J. K., T. M. Cicela, and D. W. LaCount. 2003. Responses of primiparous and multiparous Holstein cows to additional energy from fat or concentrate during summer. J. Dairy Sci. 86:13061314.

Gonthier, C., A. F. Mustafa, D. R. Ouellet, P. Y. Chouinard, R. Berthiaume, and H. V. Petit. 2005. Feeding micronized and extruded flaxseed to dairy cows: Effects on blood parameters and milk fatty acid composition. J. Dairy Sci. 88:748-756.

Griinari, J. M., B. A. Corl, S. H. Lacy, P. Y. Chouinard, K. V. V. Nurmela, and D. E. Bauman. 2000. Conjugated linolenic acid is synthesized endogenously in lactating dairy cows by $\Delta^{9}$-desaturase. J. Nutr. 130:2285-2291.

IDF. 1990. Determination of milk fat, protein and lactose contentGuide for the operation of mid-infrared instruments. FIL-IDF Standard no. 141B. International Dairy Federation, Brussels, Belgium.

IDF. 1995. Enumeration of somatic cells. FIL-IDF Standard no. 148A. International Dairy Federation, Brussels, Belgium.

Ikwuegbu, O. A., and J. D. Sutton. 1982. The effect of varying the amount of linseed oil supplementation on rumen metabolism in sheep. Br. J. Nutr. 48:365-375.

ISO-IDF. 2002. Milk fat-Preparation of fatty acid methyl esters. International Standard ISO 15884-IDF 182:2002. International Dairy Federation, Brussels, Belgium.

Kadzere, C. T., M. R. Murphy, N. Silanikove, and E. Maltz. 2002. Heat stress in lactating dairy cows: A review. Livest. Prod. Sci. 77:59-91.

Kelly, C. F., and T. E. Bond. 1971. Bioclimatic Factors and Their Measurement. A Guide to Environmental Research on Animals. Nat. Acad. Sci., Washington, DC.

Kelsey, J. A., B. A. Corl, R. J. Collier, and D. E. Bauman. 2003. The effect of breed, parity, and stage of lactation on conjugated linoleic acid (CLA) in milk fat from dairy cows. J. Dairy Sci. $86: 2588-2597$.

Kennelly, J. J. 1996. The fatty acid composition of milk fat as influenced by feeding oilseeds. Anim. Feed Sci. Technol. 60:137-152.

Knapp, D. M., and R. R. Grummer. 1991. Response of lactating dairy cows to fat supplementation during heat stress. J. Dairy Sci. $74: 2573-2579$

Lacasse, P., J. J. Kennelly, L. Delbecchi, and C. E. Ahnadi. 2002. Addition of protected and unprotected fish oil to diets for dairy cows. I. Effects on the yield, composition and taste of milk. J. Dairy Res. 69:511-520.

Liu, Z. L., P. Chen, J. M. Li, S. B. Lin, D. M. Wang, and D. P. Yang. 2008. Effect of dietary sources of roasted oilseeds on blood parameters and milk fatty acid composition. Czech J. Anim. Sci. 53:219-226.

Loor, J. J., A. Ferlay, A. Ollier, M. Doreau, and Y. Chilliard. 2005. Relationship among trans and conjugated fatty acids and bovine milk fat yield due to dietary concentrate and linseed oil. J. Dairy Sci. 88:726-740.

Luna, P., J. M. Juárez, and M. A. de la Fuente. 2005. Validation of a rapid milk fat separation method to determine the fatty acid profile by gas chromatography. J. Dairy Sci. 88:3377-3381.
McGuire, M. A., and M. K. McGuire. 2000. Conjugated linoleic acid (CLA): A ruminant fatty acid with beneficial effects on human health. J. Anim. Sci. 77:1-8.

Moody, E. G., P. J. Van Soest, R. E. McDowell, and G. L. Ford 1967. Effect of high temperature and dietary fat on performance of lactating cows. J. Dairy Sci. 50:1909-1916.

Moore, C. E., J. K. Kay, M. J. VanBaale, R. J. Collier, and L. H. Baumgard. 2005. Effect of conjugated linoleic acid on heat stressed Brown Swiss and Holstein cattle. J. Dairy Sci. 88:1732-1740.

Mustafa, A. F., P. Y. Chouinard, and D. A. Christensen. 2003. Effects of feeding micronised flaxseed on yield and composition of milk from Holstein cows. J. Sci. Food Agric. 83:920-926.

Noakes, M., P. J. Nestel, and P. M. Clifton. 1996. Modifying the fatty acid profile of dairy products through feedlot technology lowers plasma cholesterol of humans consuming the products. Am. J. Clin. Nutr. 63:42-46.

NRC. 2001. Nutrient Requirements of Dairy Cattle. 7th rev. ed. Natl Acad. Sci., Washington, DC.

Petit, H. V. 2003. Digestion, milk production, milk composition, and blood composition of dairy cows fed formaldehyde treated flaxseed or sunflower seed. J. Dairy Sci. 86:2637-2646.

Rego, O. A., H. J. D. Rosa, P. Portugal, R. Cordeiro, A. E. S. Borba C. M. Vouzela, and R. J. B. Bessa. 2005. Influence of dietary fish oil on conjugated linoleic acid, omega-3 and other fatty acids in milk fat from grazing dairy cows. Livest. Prod. Sci. 95:27-33.

Sarrazin, P., A. F. Mustafa, P. Y. Chouinard, G. Raghavan, and S. Sotocinal. 2004. Performance of dairy cows fed roasted sunflower seed . J. Sci. Food Agric. 84:1179-1185.

SAS Institute. 1999. SAS User's Guide: Statistics. Version 8.1. SAS Institute Inc., Cary, NC.

Shapiro, S. S., and M. Wilk. 1965. An analysis of variance test for normality. Biometrika 52:591-601.

Shingfield, K. J., S. Ahvenjrvi, V. Toivonen, A. Ärölä, K. V. V. Nurmela, P. Huhtanen, and J. M. Griinari. 2003. Effect of fish oil on biohydrogenation of fatty acids and milk fatty acid content in cows. Anim. Sci. 77:165-179.

Silanikove, N. 1992. Effects of water scarcity and hot environment on appetite and digestion in ruminants: A review. Livest. Prod. Sci. 30:175-194

Soita, H. W., J. A. Meier, M. Fehr, P. Yu, D. A. Christensen, J J. McKinnon, and A. F. Mustafa. 2003. Effects of flaxseed supplementation on milk production, milk fatty acid composition and nutrient utilization by lactating dairy cows. Arch. Anim. Nutr. 57:107-116.

Sukhija, P. S., and D. L. Palmquist. 1988. Rapid method for determination of total fatty acid content and composition of feedstuffs and feces. J. Agric. Food Chem. 36:1202-1206.

Ulbricht, T. L. V., and D. A. T. Southgate. 1991. Coronary heart disease: Seven dietary factors. Lancet 338:985-992.

Ward, A. T., K. M. Wittenberg, and R. Przybylski. 2002. Bovine milk fatty acid profiles produced by feeding diets containing solin, flax and canola. J. Dairy Sci. 85:1191-1196.

West, J. W., G. M. Hill, J. M. Fernandez, P. Mandebvu, and B. G. Mullinix. 1999. Effects of dietary fiber on intake, milk yield, and digestion by lactating dairy cows during cool or hot, humid weather. J. Dairy Sci. 82:2455-2465.

Zheng, H. C., J. X. Liu, J. H. Yao, Q. Yuan, H. W. Ye, J. A. Ye, and Y. M. Wu. 2005. Effects of dietary sources of vegetable oils on performance of high-yielding lactating cows and conjugated linoleic acids in milk. J. Dairy Sci. 88:2037-2042. 